\begin{tabular}{|c|l|}
\hline Title & $\begin{array}{l}\text { Identification of cultivars and accessions of Lolium, Festuca and Festulolium hy brids through the detection of simple } \\
\text { sequence repeat (SSR) polymorphism }\end{array}$ \\
\hline Author(s) & Momotaz, A liya; Forster, John W.; Y amada, Toshihiko \\
\hline Citation & $\begin{array}{l}\text { Plant Breeding, 123(4), 370-376 } \\
\text { https://doi.org/40.1111/.1439-0523.2004.00962.x }\end{array}$ \\
\hline Issue Date & 2003 \\
\hline Doc URL & http://hdl.handle.net/2115/999 \\
\hline Type & article (author version) \\
\hline File Information & PB123-4.pdf \\
\hline
\end{tabular}

Instructions for use 


\section{Identification of cultivars and accessions of Lolium, Festuca and Festulolium hybrids through the detection of simple sequence repeat (SSR) polymorphism}

Aliya Momotaz ${ }^{1,3}$, John W. Forster ${ }^{2}$ and Toshihiko Yamada ${ }^{1,4}$

${ }^{1}$ Laboratory of Grass Breeding, National Agricultural Research Center for Hokkaido Region, Sapporo, 062-8555, Japan

2Plant Biotechnology Centre, Agriculture Victoria, Department of Primary Industries, La Trobe University, Victoria 3086, Australia and Cooperative Research Centre for Molecular Plant Breeding

${ }^{3}$ Present Address: Gulf Coast Research and Education Center, University of Florida, Bradenton, FI-34203, USA

${ }^{4}$ Corresponding author, E-mail: Toshihiko.Yamada@affrc.go.jp

With 3 figures and 1 table

Received July 3, 2003 


\section{Abstract}

Molecular diversity and genetic affinity in the Lolium/Festuca grass complex have been assessed using simple sequence repeat (SSR) marker technology. The genotypic set was derived from three accessions of Lolium perenne, two cultivars of Lolium multiflorum, two cultivars of Festuca pratensis, two cultivars of Festuca arunidinacea and ten accessions from different intergeneric hybrid (Festulolium) combinations. The majority of the genomic DNA-derived SSR primer pairs from perennial ryegrass (LPSSR) and Italian ryegrass (LMSSR) produced clear, simple and distinctive amplification products from the majority of the genotypes. The efficiency of cross-specific amplification for LPSSR markers varied from $38 \%$ in F. pratensis to $93 \%$ in two cultivars of Festulolium and for LMSSR markers from $57 \%$ in $F$. pratensis to $87 \%$ in L. multiflorum. Of 40 amplified markers, fourteen (35\%) produced species-difference alleles in the relation to cultivars used in the present study. Thirty-five LPSSR locus-derived alleles were found to be specific to Lolium species, 4 to $F$. pratensis and 6 to $F$. arundinacea. For LMSSR alleles, 8 were specific to Lolium species and 5 were only associated with $L$. multiflorum, and null alleles were detected for $F$. pratensis in all instances. These species-difference markers could clearly identify different accessions of Festulolium. Cluster analysis separated the individual taxa and showed grouping of intergeneric hybrids based on genomic composition. The data distinguished between the species and reflected the known pedigree of the cultivars and the differences between the species. The dendrogram also distinguished between the Festulolium accessions and clearly demonstrated the relations between Festulolium hybrids and their parent species.

\section{Keywords}

Festuca arundinacea -- F. pratensis -- Festulolium -- Lolium multiflorum -- L. perenne -- Lolium/Festuca complex -- genetic diversity -- SSR marker 
The closely allied genera Lolium and Festuca are classified in the tribe Poeae of the sub-family Pooideae in the grass family and contain a number of important species for temperate grassland agriculture (Jauhar 1993). The Lolium genus contains only eight species, including the agronomically important taxa annual or Italian ryegrass (Lolium multiflorum Lam.) and perennial ryegrass (Lolium perenne L.). By contrast, the genus Festuca is large and diverse, including the cultivated species meadow fescue (Festuca pratensis Huds.) and tall fescue (Festuca arundinacea Schreb.). These forage grass species are all obligate outbreeders with a gametophytic self-incompatibility system (Lundqvist 1962, Cornish et al. 1979) and many commercial cultivars are derived as synthetic populations from the polycrossing of multiple parental clones.

Ryegrasses provide forage of high digestibility with good water soluble carbohydrate (WSC) content, while the fescues show superior persistency, and better ability to withstand extremes of temperatures and water availability (Thomas and Humphreys 1991). Forage grass breeders and geneticists have long aspired to combine these favourable attributes in a single genotype by producing novel Festulolium hybrids (Buckner 1960, Buckner et al. 1961, Thomas and Humphreys 1991, Jadas-Hécart et al. 1992). Intergeneric hybridisation has generated several successful amphidiploids (Breese and Lewis 1984, Kleijer 1984, Zwierzykowski et al. 1994), such as cultivar 'Prior' (L. perenne $\times$ F. pratensis: Thomas and Humphreys 1991). The high level of homoeologous chromosome pairing between the different genomes in amphidiploids leads to genetic instability and loss of hybridity in later generations. To overcome these problems, selective introgression of genes for appropriate traits from Festuca into Lolium has become a favoured methodology. This process involves the transfer of small segments of alien chromatin into the recipient genome (Humphreys 1989, Humphreys and Pašakinskiené 1996), and has been successfully employed to produce novel Festulolium lines (Humphreys and Thomas 1993).

In Festulolium hybrid breeding, it is desirable to be able to distinguish the DNA of the parental species, in order to monitor the extent of the introgressed 
regions. Fluorescence in situ hybridisation (FISH) methodology using labelled genomic DNA (genomic in situ hybridisation: GISH) has been widely used to identify alien chromatin (Thomas et al. 1994, Humphreys et al. 1995, Humphreys and Pašakinskiené 1996). However, there are potential difficulties in the identification of small introgressed chromosome segments using this technique (Humphreys et al. 1998).

The development of molecular genetic marker technologies provides alternative procedures for the assessment of genetic diversity, cultivar identification and the genomic composition of polyploid and hybrid taxa. Several marker systems have been applied to pasture grass systems including AFLP (Guthridge et al. 2001, Roldan-Ruiz et al. 2002), RAPDs (Stammers et al. 1995, Huff 1997), RFLPs (Xu and Sleper 1994, Charmet et al. 1997, Yamada and Kishida 2003). Simple sequence repeat (SSR) markers provide the current marker system of choice due to their abundance, ubiquitous distribution in plant and animal genomes, high level of reproducibility and ease of PCR-based analysis, and detection of co-dominant multiallelic loci. SSR markers are capable of surveying high levels of allelic diversity in many crop plant species, including forage grasses (Liu et al. 1995, Kubik et al. 1999, 2001, Jones et al. 2001). Moreover, SSRs have been shown to provide a powerful means for discrimination between closely related genotypes in many plant species (Yang et al. 1994, Russell et al. 1997, Röder et al. 1998). Recently, unique SSR markers derived from genomic enrichment libraries of L. perenne (LPSSR markers: Jones et al. 2001) and L. multiflorum (LMSSR markers, Fujimori et al. in preparation) have been developed. In the research described here, we have analysed the informative nature of these distinct sets of SSR markers in multiple genotypes derived from taxa of the Lolium/Festuca complex, and applied this data to investigate introgression and genetic relatedness in Festulolium accessions. 


\section{Materials and Methods}

Plant materials: Three accessions of Lolium perenne, two cultivars of $L$. multiflorum, two cultivars of Festuca pratensis, two cultivars of $F$. arundinacea and ten Festulolium accessions of different provenance were chosen as the plant material for this study (Table 1). Two of the Festulolium accessions were developed from hybridisation between $L$. perenne and F. pratensis, four from hybridisation between L. multiflorum and $F$. pratensis, two from hybridisation between $F$. pratensis and L. multiflorum (corresponding to different paternal parental origins) and two from hybridisation between $F$. arundinacea and $L$. multiflorum. Seeds of the Festulolium hybrids 'Prior' and 'B×350' were provided by Dr. Mervyn Humphreys of the Institute of Grassland and Environmental Research (IGER), Aberystwyth, UK. Seeds were germinated and grown to maturity in a glasshouse, and young seedlings were harvested for the purpose of DNA extraction.

Preparation of genomic DNA: Genomic DNA was isolated from seven individual plants from each accession using the protocol of Murray and Thompson (1980) with modifications as follows: leaf tissue $(1.5 \mathrm{~g})$ was harvested from each plant in the glasshouse and transported to the laboratory on dry ice, followed by storage at $-80^{\circ} \mathrm{C}$. The leaves were ground in the presence of liquid nitrogen and $650 \mu \mathrm{l}$ of extraction buffer (Tris- $\mathrm{HCl} 1 \mathrm{M} \mathrm{pH}$ 8.0, EDTA $0.5 \mathrm{M}, \mathrm{CTAB}$ $1.5 \%[\mathrm{w} / \mathrm{v}])$ was added. The homogenate was incubated at $65^{\circ} \mathrm{C}$ for $30 \mathrm{~min}$. Most of the proteins and polysaccharides were removed by centrifugation following the addition of $650 \mu \mathrm{l}$ chloroform/isoamyl alocohol (24:1). A volume of $100 \mu \mathrm{l}$ of $70 \%$ $(\mathrm{v} / \mathrm{v})$ ethanol was added to the supernatant. After $10 \mathrm{~min}$, the DNA was obtained as a pellet following centrifugation, then dissolved in T/E buffer $(\mathrm{pH} 8.0)$ and stored at $-20^{\circ} \mathrm{C}$ prior to further use. 
Selection of SSR primer pairs: In total, forty-four primer pairs corresponding to SSR markers were used in this study. Thirty LPSSR markers were obtained from L. perenne (Jones et al. 2001, 2002) and fourteen LMSSR markers were obtained from L. multiflorum (LMSSR, Fujimori et al. in preparation). LPSSR markers that had previously been demonstrated to efficiently amplify PCR products from L. perenne related species (Jones et al. 2001) were used in this study. Among this set, twenty LPSSR primer pairs detected polymorphic loci that were mapped on the p150/112-based reference genetic map as a framework set to cover the whole genome (Jones et al. 2002), with at least three SSR loci on each linkage group.

PCR amplification: The PCR amplification reactions for each of the SSR loci were performed in a $10 \mu \mathrm{l}$ reaction volume containing $25 \mathrm{ng}$ of genomic DNA, 1 $\mu \mathrm{l}$ of $10 \times \mathrm{PCR}$ buffer $(50 \mathrm{mM} \mathrm{KCl}, 10 \mathrm{mM}$ Tris-HCl, $\mathrm{pH}$ 8.3) (Promega, USA), $2.5 \mathrm{mM} \mathrm{MgCl} 2,0.1 \mathrm{mM}$ of each dNTP, $1 \mu \mathrm{l}$ each forward and reverse primer (20

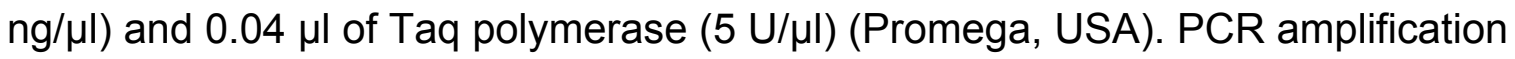
for LPSSR markers was performed in a DNA thermal cycler (Bio-Rad), as described by Jones et al. (2001).

The cycling regime for the PCR amplification of LMSSR markers consisted of an initial denaturation step of $10 \mathrm{~min}$ at $94^{\circ} \mathrm{C}$, followed by denaturation for $1 \mathrm{~min}$ at $94^{\circ} \mathrm{C}$ followed by $30 \mathrm{~s}$ at $94^{\circ} \mathrm{C}, 30 \mathrm{~s}$ at $60^{\circ} \mathrm{C}, 2 \mathrm{~min}$ at $72^{\circ} \mathrm{C}$; repeated for 35 cycles, and a final extension of $7 \mathrm{~min}$ at $72^{\circ} \mathrm{C}$ (Fujimori et al. in preparation).

Detection of SSR polymorphisms: The samples were prepared for polyacrylamide gel electrophoresis (PAGE) by addition of $2 \mu \mathrm{l}$ gel loading buffer to the reaction mixture. Ten $\mu \mathrm{l}$ of amplification products were loaded on $10 \%(\mathrm{w} / \mathrm{v})$ non-denaturing polyacrylamide gels for electrophoresis in 1×TBE. Each gel was run for $2.5 \mathrm{~h}$ at constant voltage $(250 \mathrm{~V})$. The banding patterns were visualised following staining with ethidium bromide $(50 \mu \mathrm{g} / \mathrm{ml})$ and were photographed under ultraviolet light using a transilluminator system. 
Data analysis: Only bands showing a clear polymorphism were scored as 1 for presence and 0 for absence for each genotype to produce a primary data matrix. Pair-wise comparisons of genotypes, based on the presence or absence of unique and shared polymorphic bands were used to generate similarity coefficients. The similarity coefficients were then used to determine the genetic distance between pairs of accessions on the basis of the Jaccard coefficient. The matrix of genetic distances was analysed by the unweighted pair-group method using arithmetic averages (UPGMA) by using the NTSY-pc version 2.2 software (Rohlf 1989). The genetic identity and the genetic distances (Nei and Li 1979) between the groups of the dendrogram were estimated. 


\section{Results}

\section{Cross-species amplification}

Forty-four primer pairs designed to SSR-containing genomic clones from $L$. perenne and L. multiflorum were evaluated for cross-species amplification. Of this set, 40 primer pairs (91\%) produced amplified product from all of the taxa tested. The efficiency for LPSSR locus cross-amplification ranged from 38\% ( $F$. pratensis cv. 'Tomosakae') to $93 \%$ in two cultivars of Festulolium ('Prior' and 'Perun'). For LMSSR markers, the cross-amplification values were ranged from $57 \%$ (F. pratensis cv. 'Tomosakae') to 91\% (L. multiflorum cv. 'Akiaoba') (Table 1).

\section{Species- difference alleles}

For many of the amplified marker loci, individual SSR alleles that were detected for all individuals of a given species or species group but were absent from all individuals of all other species were observed, and are here termed speciesdifference alleles in relation to the cultivars used in this study. Of the forty efficiently amplified SSR markers, fourteen primer pairs (35\%) produced speciesdifference alleles. From the total number of alleles amplified by LPSSR primer pairs, 35 were found to be specific to both of the Lolium species (L. perenne and L. multiflorum), 4 were specific to $F$. pratensis and 6 alleles were specific to $F$. arundinacea (Fig. 1). For the alleles amplified by LMSSR primer pairs, only 8 species difference alleles were found in both L. perenne and L. multiflorum, and null alleles were observed for $F$. pratensis for these markers, providing the basis for identification of Festulolium hybrids between $F$. pratensis $\times$ Lolium spp. Three of the other LMSSR primer pairs produced 5 alleles specific to L. multiflorum and common allele sizes for all of the other species studied here. The representatives of the three species groups (Lolium spp., F. pratensis and F. arundinacea) in this study were all distinguishable using a single marker detected by primer pairs designed to clone LPSSRH01A07 (SSR motif $=[\mathrm{GT}]_{9}$, genetic locus assigned to 
perennial ryegrass linkage group 2) which is of potentially high value for the identification of Festulolium hybrids from both Lolium spp. $\times$ F. pratensis and Lolium spp. $\times F$. arundinacea crosses and their reciprocal combinations. Another two markers detected by primer pairs designed to clones LPSSRK10F08 (SSR motif $=[C A A]_{12}$, genetic locus assigned to perennial ryegrass linkage group 1) and LPSSRK10H05 (SSR motif $=[\mathrm{CT}]_{26}$, genetic locus assigned to perennial ryegrass linkage group 7) produced specific alleles for each of the Lolium spp. and $F$. arundinacea but a null allele in $F$. pratensis, which is also of potential value for the identification of intergeneric Festulolium hybrids involving each of the four species.

\section{Diversity structure}

Although forty LPSSR and LMSSR primer pairs generated efficiently amplified PCR products, only thirty of them identified polymorphisms among the set of cultivars/accessions used in this study. The estimation of genetic similarity (GS) based on pair-wise comparisons of the individual genotypes within the accessions is presented in Table 1. The F. pratensis cv. 'Tomosakae' showed the highest GS value and the L. multiflorum cv. 'Waseaoba' showed the lowest GS value among the accessions. The 'Hokkai-2' had a higher GS value than the other two accessions of $L$. perenne. The cultivars of $F$. arundinacea showed high GS values, while those of the Festulolium accessions were varied and ranged from 0.903 ('Prior') to 0.950 ('Felina').

Twenty-seven polymorphic SSR markers were scored as dominant markers and were used to construct a UPGMA dendrogram based on the genetic distances between accession pairs (Fig. 2). All of the accessions of $L$. perenne, $L$. multiflorum, $F$. pratensis and $F$. arundinacea clustered separately, in accordance with the known differences between the species, with sub-clusters that reflect the known pedigree of the individual cultivars. However, the L. multiflorum clade is separated from the $L$. perenne clade by the $F$. arundinacea sub-group, despite the very close phylogenetic relationship between these two species. The $L$. perenne $\times$ F. pratensis-derived Festulolium hybrids ('Prior' and 'B×350'), which 
are believed to be true amphidiploids, were placed in between the two cognate parent species. The other Festulolium accessions ('Evergreen', 'Paulita', 'Felopa', 'Sulino', 'Perun', 'Tandem'), which are believed to be derived from L. multiflorum $\times$ F. pratensis intergeneric crosses, are clearly separated from 'Prior' and 'Bx350' and are placed near to L. multiflorum in the dendrogram. This result suggests that the majority of the genetic background of these hybrid genotypes is derived from $L$. multiflorum with selective introgression of $F$. pratensis genomic segments. The two Festulolium hybrid accessions that are thought to be derived from $F$. arundinacea $\times$ L. multiflorum intergeneric crosses ('Felina' and 'Kenhy') were located in a separate group close to the F. arundinacea clade. These two Festulolium hybrids are morphologically similar to $F$. arundinacea, and so it may be concluded that these two cultivars contain introgressed L. multiflorum genomic segments in a genetic background predominantly derived from $F$. arundinacea. As the detailed pedigree of the majority of other Festulolium cultivars was unknown, this dendrogram may only partially reflect the genetic relationships between the accessions and their putative parents.

\section{Genotype identification for Festulolium}

As indicated previously, the LPSSR marker LPSSRH1A07 produced alleles different for the Lolium spp., F. pratensis and F. arundinacea with respect to the cultivars used. These species - difference alleles were represented to different degrees in the population samples for the respective Festulolium hybrid combinations. The allele frequencies present in different Festulolium accessions derived from intergeneric crosses between Lolium spp. and F. pratensis are presented in Fig. 3. The cultivar 'Prior' and accession 'B×350' showed allele frequencies of $50 \%$, corresponding to the cumulative contributions of each parental genome. The cultivar 'Evergreen' showed a frequency of $77 \%$ for the $L$. multiflorum-derived species-deference allele as compared to $23 \%$ for the $F$. pratensis-derived species-deference allele. The cultivars 'Felopa' and 'Sulino' showed similar proportions (a frequency of $57 \%$ for the $F$. pratensis-derived 
allele as compared to $43 \%$ for the $L$. multiflorum-derived allele). The other Festulolium hybrid cultivars also showed a higher frequency of the allele derived from the L. multiflorum (61-66\%) and a lower frequency of the allele derived from F. pratensis $(34-39 \%)$. The single locus detected by primer pairs designed to clone LPSSRH07G05 (SSR motif $=[\text { TTC }]_{31}$, genetic locus assigned to perennial ryegrass linkage group 5) detected an allele common to both parental taxa, in addition to a single species-difference allele for L. multiflorum. The Festulolium cultivar accession 'Kenhy' showed a frequency of $8 \%$ for the allele derived from the L. multiflorum parent. However, analysis of Festulolium cultivar 'Felina' did not reveal any allelic contribution from the L. multiflorum parent of the hybrid. 


\section{Discussion}

In this study, primer pairs detecting Lolium SSR markers were used to analyse the genetic relationships between Festulolium accessions and their respective parental species. The levels of cross-specific amplification for the fescue species $F$. pratensis, $F$. arundinacea and the ten Festulolium accessions were very high, confirming previous observations (Jones et al. 2001, Kubik et al. 1999, 2001). The transfer efficiency of SSR markers is likely to be correlated with the phylogenetic affinity between different taxa, which is high for the Lolium and Festuca genera. In this instance, genomic DNA-derived SSR markers may be valuable for comparative genetics, although this approach is limited over larger taxonomic distances. Effective cross-amplification may be limited in most instances to members of same genus or closely related genera (Peakall et al. 1998, Echt et al. 1999).

A substantial proportion of amplified SSR markers detected alleles different to one or several taxa concerning the cultivars used. The highest number of different alleles detected by LPSSR markers was for Lolium spp. (common to both $L$. perenne and $L$. multiflorum), followed by $F$. arundinacea and $F$. pratensis respectively. No alleles different to $L$. perenne and $L$. multiflorum alone were observed. For LMSSR markers, some alleles were also different to both Lolium species and three primer pairs detected alleles different to L. multiflorum alone, while the markers detected null alleles for $F$. pratensis. The marker detected by primer pairs designed to clone LPSSRH1A07 produced diagnostic banding patterns for each of the three species and consequently could be used to discriminate almost all of the Festulolium accessions in this study. The results with species-different alleles presented here are in agreement with those of Prasad et al. (2000) and Scott et al. (2000) in wheat and Vitis species respectively.

Using the UPGMA clustering method, all accessions of $L$. perenne, $L$. multiflorum, $F$. pratensis and $F$. arundinacea could be separated according to their known species of origin. The relative position of $F$. pratensis and $F$. 
arundinacea accessions with respect to the $L$. perenne clade is consistent with known taxonomic relationships. The Lolium and Festuca genera share a monophyletic origin (Darbyshire and Warwick 1992, Xu and Sleper 1994, Charmet et al. 1997) and are closely related (Jenkins 1989). The polyploid $F$. arundinacea is thought to have arisen as a result of several interspecific hybridisation events between different Lolium and Festuca species, a hypothesis supported by both cytogenetic (Jenkin 1954) and molecular (Xu and Sleper 1994) analysis. In this study, the L. multiflorum accessions formed a separate clade distinct from the other species. This result is inconsistent with the data of Śiffelová et al. (1997). However, Charmet and Balfourier (1994) reported the clustering of $L$. perenne and $L$. multiflorum in different groups.

The true Festulolium amphidiploids 'Prior' and 'Bx350' were also located according to their known pedigree. However, the other eight Festulolium clustered adjacent either to L. multiflorum or $F$. arundinacea. This data suggested that the majority of the Festulolium hybrids of $L$. multiflorum $\times F$. pratensis origin have a predominant $L$. multiflorum genetic background with limited introgression from F. pratensis. However, the cultivars 'Felopa' and 'Sulino' were reported to be amphidiploids between $F$. pratensis and L. multiflorum (Zwierzykowski et al. 1998) and showed a similar different allele frequency from each of their parent species. The Festulolium cultivars 'Felina' and 'Kenhy' were located close to F. arundinacea in the dendrogram. This is consistent with the data of Buckner et al. (1977). The low frequency of the allele derived from L. multiflorum in cultivar 'Kenhy' is consistent with its breeding history. However, no allele derived from $L$. multiflorum was detected in cultivar' Felina'. The breeding history of this cultivar is unknown.

The accessions of different species studied here showed wide or narrow genetic bases according to the genetic distances between parental clones. Levels of genetic variability may also be affected by the number of foundation clones used in the cultivar development, leading to a restricted or non-restricted genetic base (Forster et al. 2001, Guthridge et al. 2001). The estimation of genetic similarity (GS) within the accessions in this study is influenced by these 
two factors. The F. pratensis cv. 'Tomosakae' showed the lowest internal genetic variability and the L. multiflorum cv. 'Waseaoba' had the highest internal genetic variability among the varieties of grasses studied here. 'Tomosakae' is a synthetic cultivar developed from only four clones, while 'Waseaoba' is a longestablished cultivar developed through mass selection from a Japanese ecotype. Yamada and Kishida (2003) demonstrated similar results for 'Tomosakae' using RFLP markers. The L. perenne accession 'Hokkai-2' accession is a tetraploid synthetic, showing lower within-variety variability compared to the diploid accessions 'Yatsugatake D-12' and 'Yatsugatake D-13'. In general, tetraploid cultivars showed lower genetic variability due to narrow genetic base. In this study, accessions of $F$. pratensis showed low within-cultivar variability compared to L. multiflorum and L. perenne, consistent with the data of Kölliker et al. (1999) using RAPD markers. The genetic variability of two hexaploid $F$. arundinacea cultivars was also found to be lower than that of $L$. perenne and $L$. multiflorum accessions.

In conclusion, SSR markers derived from L. perenne and L. multiflorum provide an opportunity to estimate levels of relatedness among breeding materials. Species-difference alleles are suitable for rapid quantification of genotype similarities in Festulolium of different combinations. The selected SSR markers may consequently be used for clone and cultivar identification and for implementation in Festulolium breeding. 


\section{Acknowledgements}

The authors gratefully acknowledge Prof. G. Spangenberg of the Plant Biotechnology Centre, Department of Primary Industries, La Trobe University, Victoria, Australia and Mr. M. Fujimori of National Institute of Livestock and Grassland Science, Tochigi, Japan for providing the information regarding the LPSSR and LMSSR markers respectively; Mr. H. Enoki, National Agricultural Research Center for Hokkaido Region for his valuable technical suggestions. Thanks are due to Dr. M. O. Humphreys, Institute of Grassland and Environmental Research, Aberystwyth, UK for supplying seeds of the Festulolium hybrids 'Prior' and 'Bx350' and Mr. J. Yonemaru, National Agricultural Research Center for Tohoku Region, Morioka, Japan for supplying seeds of some Festulolium cultivars. The work was partially supported by the fund from the Ministry of Agriculture, Forestry and Fisheries of Japan. This first author was supported by a STA Fellowship from Japan International Science and Technology Exchange Center. 


\section{References}

Breese, E.L., and E.J. Lewis, 1984: Breeding versatile hybrid grasses. Span 27, 3-5.

Buckner, R.C., 1960: Cross-compatibility of annual and perennial ryegrasses with tall fescue. Agron. J. 52, 409-410.

Buckner, R.C., H.D. Hill and P.B. Burrus Jr., 1961: Some characteristics of perennial and annual ryegrass $\times$ tall fescue of the amphidiploid progenies of annual ryegrass $\times$ tall fescue. Crop Sci. 1, 75-80.

Buckner, R.C., P.B. Burrus, II, and L.P. Bush, 1977: Registration of Kenhy tall fescue. Crop Sci. 17, 672-673.

Charmet, G., and F. Balfourier, 1994: Isozyme variation and species relationships in the genus Lolium L. (ryegrasses, Graminaceae). Theor. Appl. Genet. 87, 641-649.

Charmet, G., C. Ravel, and F. Balfourier, 1997: Phylogenetic analysis in the Festuca-Lolium complex using molecular and ITS rDNA. Theor. Appl. Genet. 94, 1038-1046.

Cornish M.A., M.D. Hayward, and M.J. Lawrence, 1979: Self-incompatibility in ryegrass. I genetic control in diploid Lolium perenne. Heredity 43, 95-106.

Darbyshire, S.J., and S.I. Warwick, 1992: Phylogeny of North American Festuca (Poaceae) and related genera using chloroplast DNA restriction site variation. Can. J. Bot. 70, 2415-2429.

Echt, C.S., G.G. Vendranin, C.D. Nelson, and P. Marquardt, 1999: Microsatellite DNA as shared markers among conifer species. Can. J. For. Res. 29, 365371.

Forster, J.W., E.S. Jones, R. Kölliker, M.C. Drayton, M.P. Dupal, K.M. Guthridge, K.F. Smith, 2001: DNA profiling in outbreeding forage species. In: R. Henry (ed.) Plant genotyping - the DNA fingerprinting of plants pp. 299-320, CABI Press. 
Guthridge, K.M., M.D. Dupal, R. Kölliker, E.S. Jones, K.F. Smith, J.W. Forster, 2001: AFLP analysis of genetic diversity within and between populations of perennial ryegrass (Lolium perenne L.). Euphytica 122,191-201.

Huff, D.R., 1997: RAPD characterization of heterogeneous perennial ryegrass cultivars. Crop Sci. 37, 557-564.

Humphreys, M.W., 1989: The controlled introgression of Festuca arundinacea genes into Lolium multiflorum. Euphytica 42, 105-116.

Humphreys, M.W., and H. Thomas, 1993: Improved draught resistance in introgression lines derived from Lolium multiflorum $\times$ Festuca arundinacea hybrids. Plant Breed. 111, 155-161.

Humphreys, M.W., H.M. Thomas, W.G. Morgan, M.R. Meredith, J.A. Harper, H. Thomas, Z. Zwierzykowski, and M. Ghesquiere, 1995: Discriminating the ancestral progenitors of hexaploid Festuca arundinacea using genomic in situ hybridization. Heredity 75, 171-174.

Humphreys, M.W., and I. Pašakinskiené, 1996: Chromosome painting to locate genes for drought resistance transferred from Festuca arundinacea into Lolium multiflorum. Heredity 77, 530-534.

Humphreys, M.W., I. Pašakinskiené, A.R. James, and H. Thomas, 1998: Physically mapping quantitative traits stress-resistance in forage grasses. J. Exp. Bot. 49, 1611-1618.

Jadas-Hécart J., C. Poisson, J. Scehovic, and Z. Zwierzykowski, 1992: Potential of tetraploid hybrids between Lolium multiflorum and Festuca arundinacea var. glaucescens. In: Ploidy and chromosome manipulation in forage breeding. EUCARPIA Meeting of the Fodder Crop Section, Alghero, Italy, Oct. 1991.

Jauhar, P.P., 1993: Cytogenetics of the Festuca-Lolium Complex. Monographs on Theoretical and Apllied Genetics 18, Springer-Verlag, Berlin.

Jenkin, T.J., 1954: Interspecific and intergeneric hybrids in herbage grasses. J. Genet. 53, 442-466. 
Jenkins, G., 1989: Chromosome pairing and fertility in plant hybrids. In: C.B.Gillies (ed.), Fertility and chromosome pairing: recent studies in plants and animals pp. 109-135, CRC Press. Boca Raton, Florida.

Jones, E.S., M.P. Dupal, M.C. Kölliker, M.C. Drayton, and J.W. Forster, 2001: Development of and characterization of simple sequence repeat (SSR) markers for perennial ryegrass (Lolium perenne L.) Theor. Appl. Genet. 102, 405-415.

Jones, E.S., M.P. Dupal, J.L. Dumsday, L.J. Hughes, and J.W. Forster, 2002: An SSR-based genetic linkage map for perennial ryegrass (Lolium perenne L.) Theor. Appl. Genet. 105, 577-584.

Kleijer, G., 1984: Cytogenetic studies of crosses between Lolium multiflorum Lam. and Festuca arundinacea Schreb.: I. The parents and their $F_{1}$ hybrids. $Z$. Pflanzenzucht 93, 1-22.

Kölliker, R., F.J. Stadelmann, B. Reidy, and J. Nosberger, 1999: Genetic variability of forage grass cultivars: a comparison of Festuca pratensis Huds., Lolium perenne L. and Dactylis glomerata L. Euphytica 106, 261-270.

Kubik, C., W.A. Meyer, and B.S. Gaut, 1999: Assessing the abundance and polymorphism of simple sequence repeats in perennial ryegrass. Crop Sci. 39, 1136-1141.

Kubik, C., M. Sawkins, W.A. Meyer, and B.S. Gaut, 2001: Genetic diversity in seven perennial ryegrass (Lolium perenne L.) cultivars based on SSR markers. Crop Sci. 41, 1565-1572.

Liu, Z.W., R.L. Jarret, S. Kresovich, and R.R. Duncan, 1995: Characterization and analysis of simple sequence repeat (SSR loci) in sea-shore paspalum (Paspalum vaginatum Swartz.). Theor. Appl. Genet. 91, 47-52.

Lundqvist, A., 1962: The nature of the two loci incompatibility system in grasses. I. The hypothesis of a duplicative origin. Hereditas 48, 153-168.

Murray, M.G., and W.F. Thompson, 1980: Rapid isolation of high molecular weight plant DNA. Nucleic Acids Res. 18, 4321-4325. 
Nei, M., and W.H. Li, 1979: Mathematical model for studying genetic variation in terms of restriction endonucleases. Proc. Natl. Acad. Sci. USA 76, 52695273.

Peakall, R., S. Gilmore, W. Keys, M. Morgante, and A. Rafalski, 1998: Crossspecies amplification of soybean (Glycine max) simple-sequence-repeats (SSRs) within the genus and other legume genera. Mol. Biol. Evol. 15, 12751287

Prasad, M., R. K. Varshney, J. K. Roy, H. S. Balyan, and P. K. Gupta, 2000. The use of microsatellites for detecting DNA polymorphism, genotype identification and genetic diversity in wheat. Theor. Appl. Genet. 100, 584592.

Röder, M.S., V. Korzum, K. Wendehake, J. Plaschke, M.-H. Tixier, P. Leroy, and M.W. Ganal, 1998: A microsatellite map of wheat. Genetics 149, 2007-2023.

Rohlf, F.J., 1989: NTSYS-pc: Numerical taxonomy and multivariate analysis system, version 2.00, Exeter Software, New York.

Roldan-Ruiz, I., J. Dendauw, E. Van Bockstaele, A. Depicker, and M. De Loose, 2002: AFLP markers reveal high polymorphic rates in ryegrasses (Lolium spp.). Mol. Breed. 6, 125-134.

Russell, J., J. Fuller, G. young, B. Thomas, G. Taramino, M. Macaulay, R. Waugh, and W. Powell, 1997: Discriminating between barley genotypes using microsatellite markers. Genome 40, 442-450.

Scott, K.D., P. Eggler, G. Seaton, M. Rossetto, E.M. Ablett, L.S. Lee, and R.J. Henry, 2000. Analysis of SSRs derived from grape ESTs. Theor. Appl. Genet. 100, 723-726.

Śiffelová, G., M. Pavelková, A. Klabouchová, I. Wiesner, and V. Naśinec, 1997: Computer-aided RAPD fingerprinting of accessions from the ryegrass-fescue complex. J. Agric. Sci. 129, 257-265.

Stammers, M., J. Harris, G.M. Evans, M.D. Hayward, and J.W. Forster 1995: Use of random PCR (RAPD) technology to analyse the phylogenetic relationships in the Lolium/Festuca complex. Heredity 74, 19-27. 
Thomas, H., and M.O. Humphreys, 1991: Review: progress and potential of interspecific hybrids of Lolium and Festuca. J. Agric. Sci. 117,1-8.

Thomas, H.M., W.G. Morgan, M.R. Meredith, M.W. Humphreys, H. Thomas, and J.M. Leggett, 1994: Identification of parental and recombined chromosomes in hybrid derivatives of Lolium multiflorum $\times$ Festuca pratensis by genomic in situ hybridization. Theor. Appl. Genet. 88, 909-913.

Xu, W.W., and D.A. Sleper, 1994: Phylogeny of tall fescue and related species using RFLPs. Theor. Appl. Genet. 88, 909-913.

Yamada, T., and T. Kishida, 2003: Genetic analysis of forage grasses based on heterologous RFLP markers detected by rice cDNAs. Plant Breed. 122, 5760.

Yang, G.P., M.A. Maroof, C.G. Xu, Q. Zhang, and R.M. Biyashev, 1994: Comparative analysis of microsatellite DNA polymorphism in landraces and cultivars of rice. Mol. Gen. Genet. 245, 187-194.

Zwierzykowski, Z., W. Joks, and B. Naganowska, 1994: Potential of tetraploid (Festuca pratensis $\times$ L. multiflorum). In: Rognli, O.A., E. Solberg and I. Schjelerup (ed.) Breeding Fodder Crops for Marginal Conditions, pp. 299-300. Kluwer, Dordrecht.

Zwierzykowski, Z., R. Tayyar, M. Brunell, and A.J. Likaazewski, 1998: Genome recombination in intergeneric hybrids between tetraploid Festuca pratensis and Lolium multiflorum. J. Hered. 89, 324-328. 


\section{Figure Legends}

Fig. 1: Number of species-difference alleles detected in Lolium spp., F. pratensis and $F$. arundinacea $(\mathrm{Lm}=L$. multiflorum, $\mathrm{Fa}=F$. arundinacea, $\mathrm{Fp}=F$. pratensis) with the genomic DNA-derived SSR primer pairs from perennial ryegrass (LPSSR) and Italian ryegrass (LMSSR).

Fig. 2: UPGMA dendrogram for individual plants from accessions of $L$. perenne, L. multiflorum, F. pratensis, F. arundinacea and Festulolium calculated using measurements of average taxonomic distance.

Fig. 3: Frequency of alleles in populations of different Festulolium accessions detected by the marker LPSSRH01A07 (SSR motif $\left.=[G T]_{9}\right)$. 
Table 1: Estimates of mean genetic similarity (GS) within cultivars and percent of cross-species amplification obtained by the SSR primer pairs from perennial ryegrass (LPSSR) and Italian ryegrass (LMSSR)

\begin{tabular}{|c|c|c|c|c|c|c|}
\hline \multirow{2}{*}{\multicolumn{2}{|c|}{ Species }} & \multirow[t]{2}{*}{ Cultivar/Line } & \multirow[t]{2}{*}{ Ploidy level } & \multirow[t]{2}{*}{ Mean $\mathrm{GS}^{* * * *}$} & \multicolumn{2}{|c|}{ Cross-species amplification (\%) } \\
\hline & & & & & LPSSR Loci & LMSSR Loci \\
\hline \multirow{3}{*}{\multicolumn{2}{|c|}{ Lolium perenne }} & 'Yatsugatake D-12' * & Diploid & 0.929 & 84 & 61 \\
\hline & & 'Yatsugatake D-13' * & Diploid & 0.911 & 81 & 65 \\
\hline & & 'Hokkai-2' ** & Tetraploid & 0.934 & 80 & 67 \\
\hline \multirow{2}{*}{\multicolumn{2}{|c|}{ Lolium multiflorum }} & 'Waseaoba' & Diploid & 0.880 & 67 & 87 \\
\hline & & 'Akiaoba' & Tetraploid & 0.894 & 82 & 91 \\
\hline \multirow{2}{*}{\multicolumn{2}{|c|}{ Festuca pratensis }} & 'Harusakae' & Diploid & 0.951 & 43 & 59 \\
\hline & & 'Tomosakae' & Diploid & 0.972 & 38 & 57 \\
\hline \multirow{2}{*}{\multicolumn{2}{|c|}{$F$. arundinacea }} & 'Hokuryo' & Hexaploid & 0.938 & 59 & 74 \\
\hline & & 'Yamanami' & Hexaploid & 0.934 & 58 & 72 \\
\hline \multicolumn{7}{|l|}{ Festuloium } \\
\hline \multirow[t]{2}{*}{ L. perenne } & $\mathrm{x} F$. pratensis & 'Prior' & Tetraploid & 0.903 & 93 & 83 \\
\hline & & 'Bx350' *** & Tetraploid & 0.933 & 79 & 80 \\
\hline \multirow[t]{4}{*}{ L. multiflorum } & x F. pratensis & 'Evergreen' & Tetraploid & 0.916 & 91 & 80 \\
\hline & & 'Paulita' & Tetraploid & 0.915 & 90 & 85 \\
\hline & & 'Perun' & Tetraploid & 0.909 & 93 & 81 \\
\hline & & 'Tandem' & Tetraploid & 0.930 & 89 & 81 \\
\hline \multirow[t]{2}{*}{ F. pratensis } & $x$ L. multiflorum & 'Felopa' & Tetraploid & 0.926 & 91 & 85 \\
\hline & & 'Sulino' & Tetraploid & 0.927 & 84 & 83 \\
\hline \multirow[t]{2}{*}{ F. aurandinacea } & $\times L$. multiflorum & 'Felina' & Hexaploid & 0.950 & 59 & 72 \\
\hline & & 'Kenhy' & Hexaploid & 0.948 & 64 & 69 \\
\hline
\end{tabular}

* Lines developed at the Yamanashi Prefectural Dairy Experimental Station, Japan

** Line developed at the National Agricultural Research Center for Hokkaido Region, Japan

*** Line developed at the Institute of Grassland and Environmental Research, UK

**** Genetic similarity 
Momotaz, Forster, and Yamada

Fig. 1: Number of species-difference alleles detected

Top

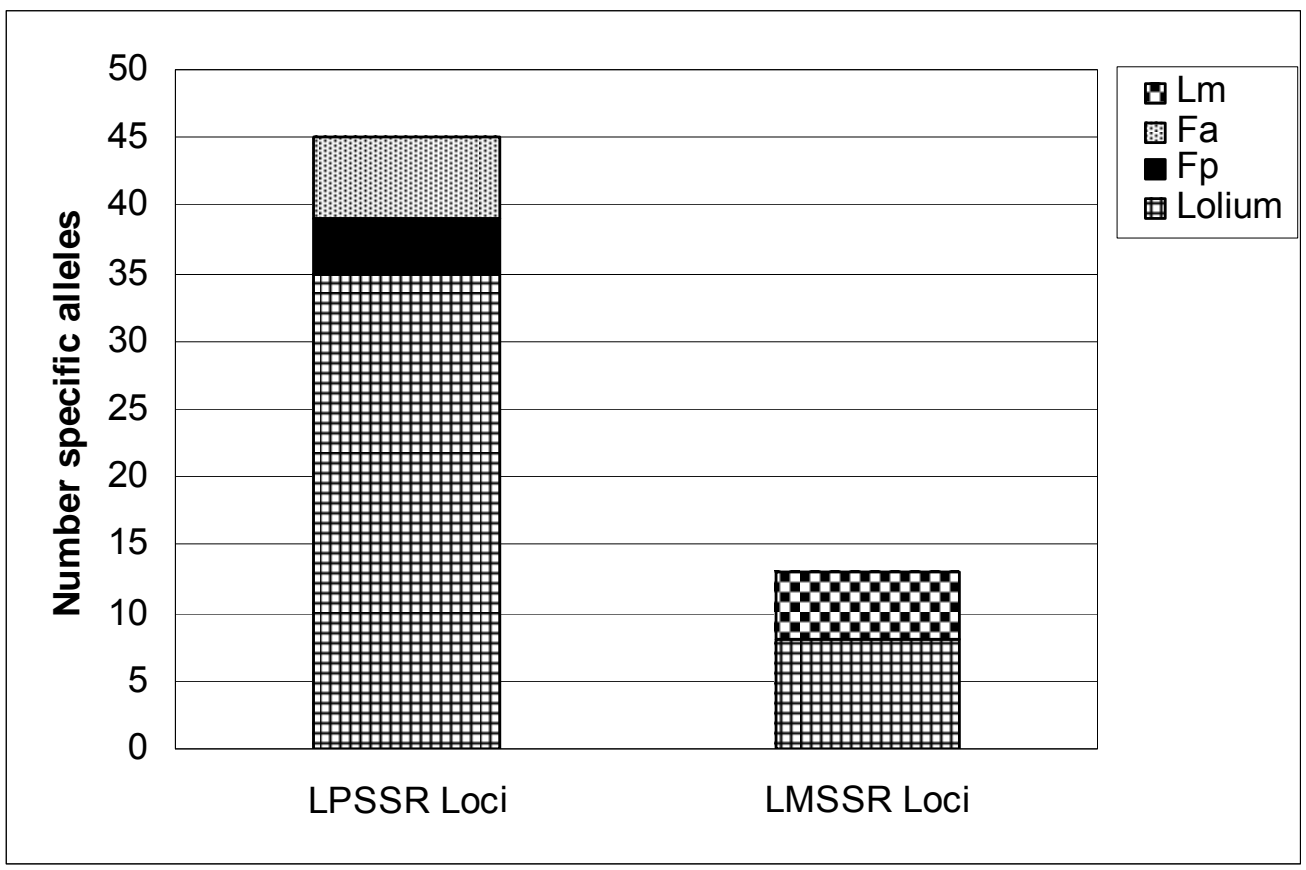




\section{Momotaz, Forster, and Yamada Fig. 2: UPGMA dendrogram}

Top

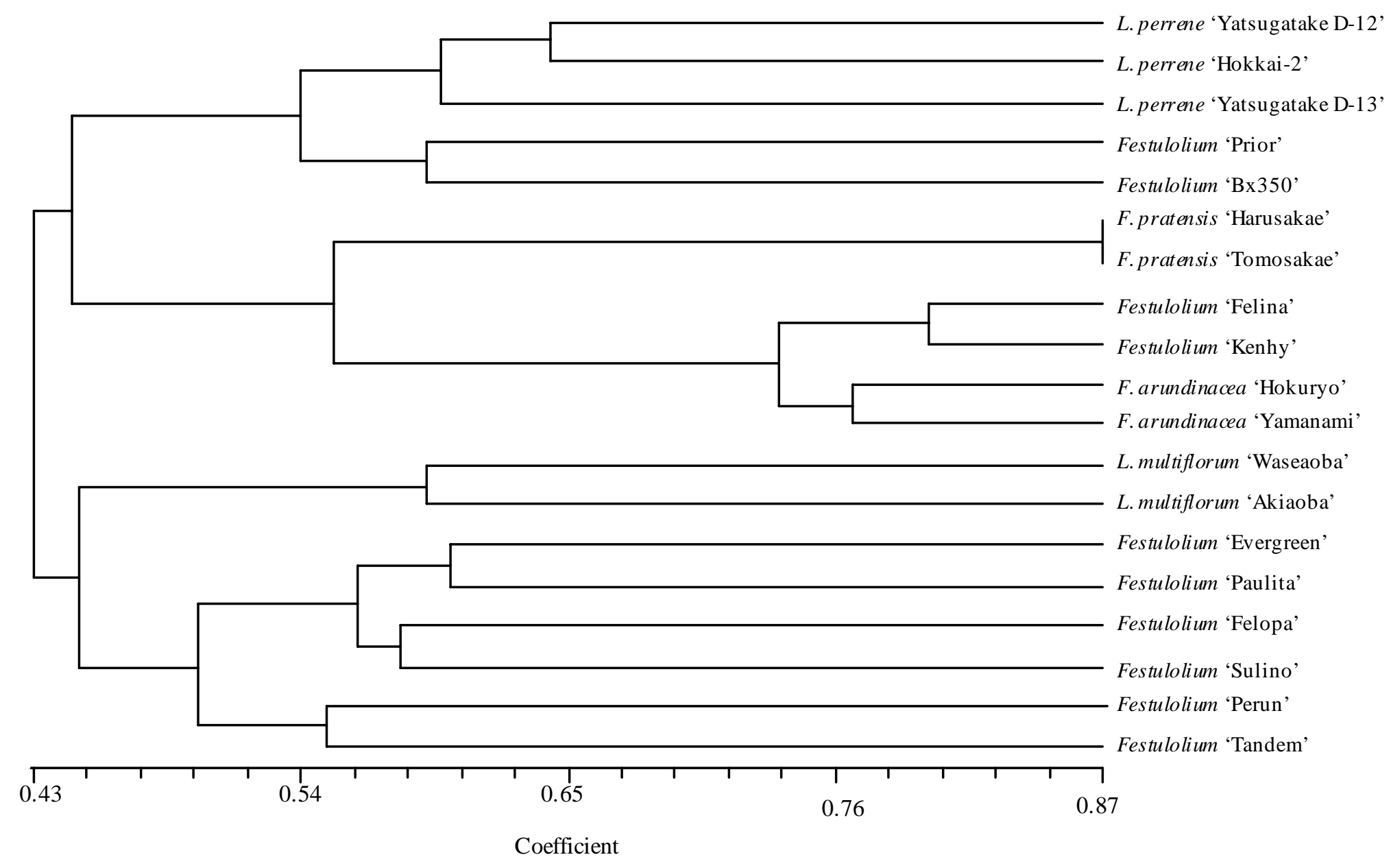


Momotaz, Forster, and Yamada

Fig. 3: Frequency of alleles in populations of different Festulolium accessions detected by the marker LPSSRH1A07

Top

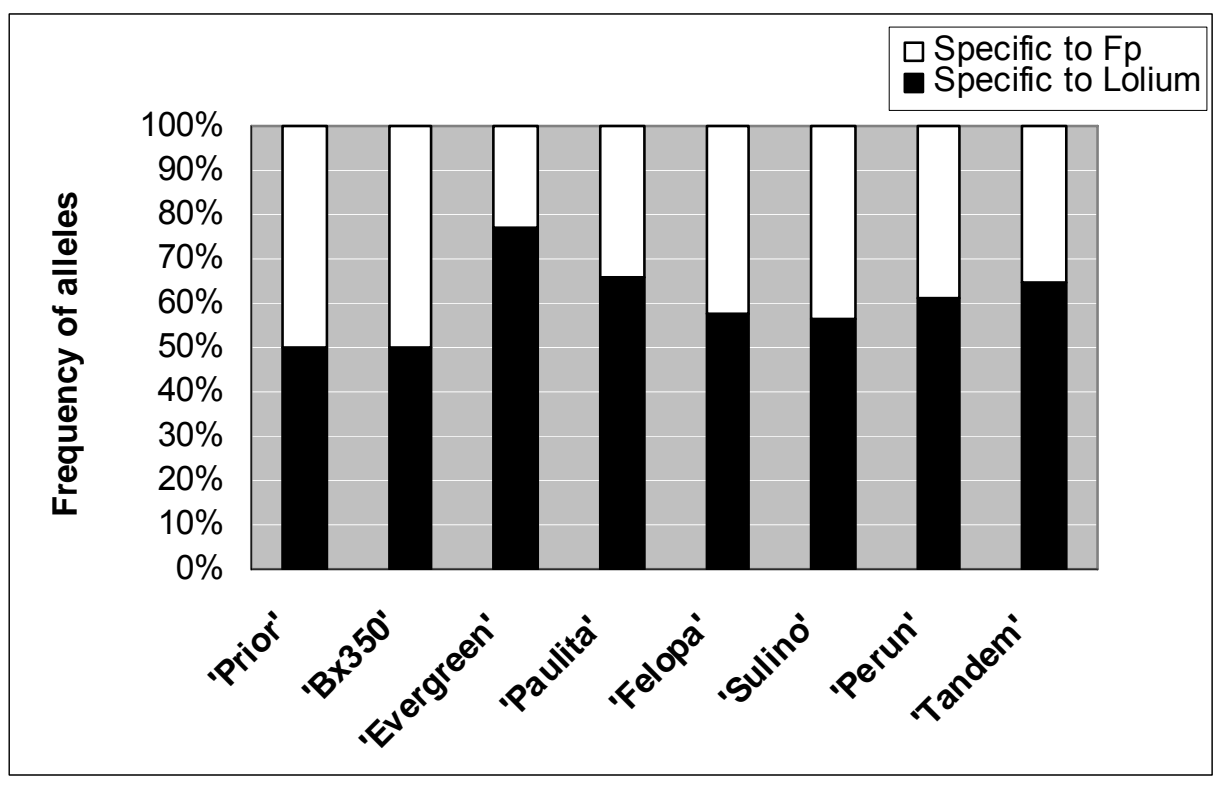

